

\section{DISCLAIMER}

This report was prepared as an account of work sponsored by an agency of the United States Government. Neither the United States Government nor any agency Thereof, nor any of their employees, makes any warranty, express or implied, or assumes any legal liability or responsibility for the accuracy, completeness, or usefulness of any information, apparatus, product, or process disclosed, or represents that its use would not infringe privately owned rights. Reference herein to any specific commercial product, process, or service by trade name, trademark, manufacturer, or otherwise does not necessarily constitute or imply its endorsement, recommendation, or favoring by the United States Government or any agency thereof. The views and opinions of authors expressed herein do not necessarily state or reflect those of the United States Government or any agency thereof. 


\section{DISCLAIMER}

Portions of this document may be illegible in electronic image products. Images are produced from the best available original document. 
The facilities of Argonne National Laboratory are owned by the United States Government. Under the terms of a contract (W-31-109-Eng-38) among the U. S. Department of Energy, Argonne Universities Association and The University of Chicago, the University employs the staff and operates the Laboratory in accordance with policies and programs formulated, approved and reviewed by the Association.

\section{MEMBERS OF ARGONNE UNIVERSITIES ASSOCIATION}

The Univer sity of Arizona

Carnegie-Mellon University

Case Western Reserve University

The University of Chicago

University of Cincinnati

Illinois Institute of Technology

University of Illinois

Indiana University

The University of lowa

Iowa State University
The University of Kansas

Kansas State University

Loyola University of Chicago

Marquette University

The University of Michigan

Michigan State University

University of Minne sota

University of Missouri

Northwe stern Univer sily

University of Notre Dame
'I'he Ohio State University

Ohio University

The Pennsylvania State University

Purdue University

Saint Louis University

Southern Illinois University

The University of Texas at Austin

Washington University

Wayse Glale Unives sity.

The Universily of Wiscunsin"Mladisun

\section{NOTICE}

This report was prepared as an account of work sponsored by the United States Government. Neither the United States nor the United States Department of Energy, nor any of their employees, nor any of their contractors, subcontractors, or their employees, makes any warranty, express or implied, or assumes any legal liability or responsibility for the accuracy, completeness or usefulness of any information, apparatus, product or process disclosed, or represents that its use would not infringe privately-owned rights. Mention of commercial products, their manufacturers, or their suppliers in this publication does not imply or connote approval or disapproval of the product by Argonne National Laboratory or the U. S. Department of Energy.

Printed in the United States of America

Available from

National Technical Information Service

U. S. Department of Commerce

5285 Port Royal Road

Springfield, Virginia 22161

Price: Printed Copy $\$ 4.50 ;$ Microfiche $\$ 3.00$ 
ANL/OTEC - BCM-003

Qualification of Aluminum for OTEC Heat Exchangers

by

F. L. LaQue

ERRATUM

\section{Page 6}

The: third line from the bottom of the page should read as follows:

do.qualify Alclad 3003 or 3004 and the 5052

alloy as candidates worthy of

July 12,1979 
Distribution Category:

Ocean Thermal Energy

Conversion (UC-64)

ANL / OTEC - BCM - 003

ARGONNE NATIONAL LABORATORY

9700 South Cass Avenue

Argonne, Illinois 60439

QUALIFICATION OF ALUMINUM FOR OTEC HEAT EXCHANGERS

\author{
F. L. LaQue \\ Claridge Drive \\ Verona, New Jersey 97944
}

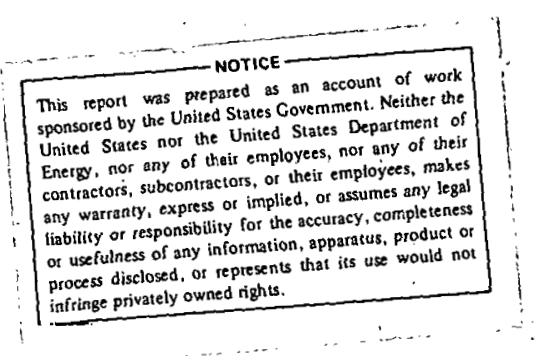

May 1979

$\because$ 
EXECUTIVE SUMMARY $\quad$ • . . . . . . . . . . . . . . . . 5

ABSTRACT

I. INTRODUCTION

II. DETAILS PERTINENT TO QUALIFICATION OF ALUMINUM FOR OTEC. SYSTEMS COMPONENTS AND, PARTICULARLY, HEAT EXCHANGERS • • • 10

III. PITTING . . . . . . . . . . . . . . . 15

IV. CURRENT CORROSION RESEARCH

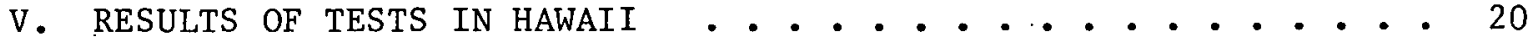

VI. TESTS AT ST. CROIX . . . . . . . . . . . . . . . 21

VII. TESTS IN THE GULF OF MEXICO • • • • • • • • • • • • • • 22

VIII. CREVICE CORROSION . . . . . . . . . . . . . . . 22

IX. EFFECTS OF FLOW VELOCITY . . . . . . . . . . . . 24

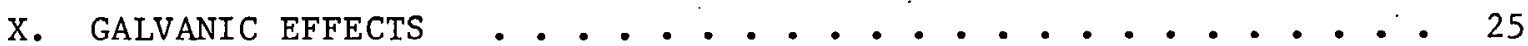

XI. EFFECTS OF CHLORINATION . • • • • • • • • • • • • 25

XII. EFFECTS OF AMMONIA . . . . . . . . . . . . . . . 25

XIII. EFFECTS OF VIBRATION

A. Corrosion Fatigue . . . . . . . . . . . . . . 27

B. Fretting . . . . . . . . . . . . . . 27

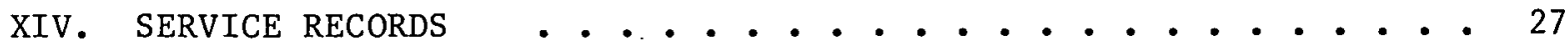

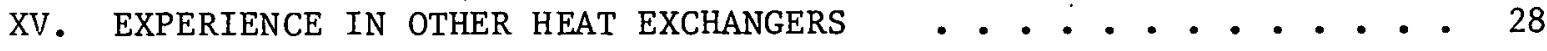

XVI. SUMMARY OF SERVICE RECORDS . . . . . . . . . . . . . . 28

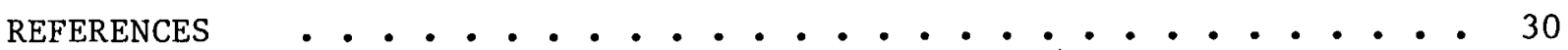


THIS PAGE

\section{WAS INTENTIONALLY LEFT BLANK}




\title{
QUALIFICATION OF ALUMINUM FOR OTEC HEAT EXCHANGERS
}

\author{
F. L. LaQue
}

\section{EXECUTIVE SUMMARY}

1.* Aluminum can neither be qualified nor disqualified for use as tubes in OTEC heat exchangers on the basis of available data on resistance to corrosion especially by pitting or corrosion in crevices. Alloys identified as being worthy of additional studies under conditions properly related to OTEC service are Alclad (7072) 3003 or 3004 and Al 5052. In view of the thin walls of heat-exchanger tubes, the prime requirement is resistance to penetration by pitting. This suggests Alclad would have a considerable advantage, based on the ability of the cladding to arrest penetration of the core alloy, so long as a substantial area of cladding is able to survive.

A principal target of further testing should be to establish whether periodic cleaning will increase the loss of cladding above the approximately 1 mil per year indicated by behavior in the absence of any effects of cleaning. Available data suggest a possible life of about 10 years** for Alclad tubes with 10 mils of cladding. This assumes the development of effective cleaning treatments that would not seriously impair resistance to corrosion.

2. Corrosion testing programs that will clarify the suitability of aluminum for OTEC heat-exchanger tubes are being or will be carried out in Hawaii, Puerto Rico, Gulf of Mexico, Harbor Island, North Carolina, and possibly at other locations. These tests on the Alclad 3003 and 5052 alloys will be under conditions of flow, cleaning to remove fouling, and treatments to prevent fouling that may be encountered in OTEC heat exchangers.

3. The danger of crevice corrosion will have to be taken into account in connection with the use of aluminum in designs where crevices cannot be avoided, such as plate-type heat exchangers, or may be difficult to seal, as at tube supports in heat exchangers with water outside the tubes. Crevice corrosion seems likely to be more severe in condensers handling water from great depths.

4. A design velocity of flow of water below $8 \mathrm{ft} / \mathrm{sec}$ is not expected to result in intolerable erosion of aluminum. Crevice corrosion is accelerated by movement of water. This could be more of a problem in plate-type heat exchangers and in those with water outside the tubes.

* For details in support of this and other conclusions in this Summary, see corresponding items in the text discussion.

**Representatives of the aluminum industry have suggested that the estimate of 10 years as the life of Alclad tubes is too conservative because it does not give sufficient credit to the survival of the core alloy after the cladding is gone. In view of uncertainties relative to the effects of cleanting on the life of the cladding and possibly high rates of subsequent pitting of the core alloy, the author is inclined to stick to his estimate of a 10-year life, pending development of data from new tests that could support an expectation of a longer life. 
5. The vulnerability of aluminum to acceleration of corrosion by galvanic action in contact with most other metals needed for OTEC system components and by effects of heavy metals (copper) from corrosion upstream of aluminum will limit choices of materials for such components.

This could increase costs of such components and limit means of avoiding fouling in piping, screens, and water boxes by use of copper alloys naturally resistant to fouling by barnacles, etc.

Electrical insulation of dissimilar metals and elimination of heavymetal corrosion products in the seawater stream are important. In this context, avoidance of sources of copper is likely to be more important than avoidance of sources of iron.

6. The fear of possible effccts of leakage of ammonia in accelerating corrosion of aluminum has been found to be less significant than a more drastic ettect of ammonia leakage in triggering intolerable deposition of carbonate scale from water likely to be supersaturated with calcium carbonate. This, plus the economic penalty of loss of ammonia by leakage, will require extraordinary steps to prevent, detect and correct even slight leakage of ammonia in OTEC heat exchangers, irrespective of the metal to be used.

The danger of scaling associated with leakage of ammonia will be much greater in plate-type heat exchangers. Leakage through a single plate could trigger deposition of scale on the surfaces of many plates downstream of the original source of a nucleating precipitate.

There is also the possibility that scale deposition could be triggered by nuclei carried into the main body of water by brushes or balls used for mechanical cleaning.

There is what may be no more than a temporary impediment to the use. of aluminum in contact with ammonia. Such use is prohibited currently hy II. S. Coast Guard Regulation CG-257. However, aluminum is permitted by a pending IMCO (Inter-Governmental Maritime Consultative Organization) Standard. The latter may be taken into account, along with new data showing aluminum to be satisfactorily resistant to attack by ammonia, in action that may be taken by the Coast Guard to waive their prohibition of al.uminum as applied to U'L'E' systems.

7. Experience has shown that the possibility of encountering harmful vibration of tubes in heat exchangers will require careful attention in design to avoid trouble from this source. A proper design will involve such considerations as fluid velocity, the dimensions of tubes, the physical properties of the tube material and properly related spacing of tube supports. Despite the relatively low corrosion fatigue strength of aluminum, 21 experience 24 suggests that failure of aluminum tubes by corrosion fatigue need not present a problem in properly designed heat exchangers.

8. Records of service appropriately related to OTEC heat exchangers are not sufficient to either qualify or disqualify aluminum $f$ or this use. They do not qualify Alclad 3003 or 3004 and the 5052 alloy as candidates worthy of continuing evaluation. Of the two, the performance records for Alclad give it an advantage over the 5052 alloy for shell and tube heat exchangers. 
The situation with respect to plate-type heat exchangers is clouded by reported failures of aluminum by crevice corrosion in desalination service and by experience reported by manufacturers of this type of heat exchanger. Alclad would appear to be the better choice in any further efforts to qualify aluminum for this application. Special attention should be paid to the choice of adhesive to seal crevices under gaskets.

9. There should be no problem of stress-corrosion cracking of aluminum in either sea water or ammonia.

10. There is no problem of supply of aluminum ore and of aluminum metal that would restrain the use of aluminum in any probable scale of OTEC operations. There may be restrictions on the extended surface configurations available in Alclad or 5052 alloy especially in the form of welded tubing. 


\section{THIS PAGE \\ WAS INTENTIONALLY \\ LEFT BLANK}




\title{
QUALIFICATION OF ALUMINUM FOR OTEC HEAT EXCHANGERS
}

\author{
F. L. LaQue
}

\section{ABSTRACT}

This paper reviews the basis for qualification of aluminum as a material for use as tubing in Ocean Thermal Energy Conversion heat exchangers.

Reference is made to compendia of data from tests of aluminum alloys in natural sea water and to applicable service records. Data from these sources were found to be inadequate to either qualify or disqualify aluminum. They serve only to identify the 5052 alloy and Alclad 3003 or 3004 as being worthy of additional testing under conditions more directly related to what will be encountered in OTEC heat exchangers.

The principal deficiency of data from long-time tests in natural sea water is that in almost all of these tests the specinens were exposed under static conditions that caused the surfaces to be covered by marine fouling organisms that would not be present in heat exchanger tubes. The tests did not take into account possible effects of periodic mechanical or chemical treatments to remove fouling or chemical treatments (chlorination) to prevent fouling. A current testing program sponsored by the Department of Energy through Argonne National Laboratory is designed to provide the needed data.

Limited tests in high velocity sea water have indicated that aluminum tubes would tolerate the velocities under $10 \mathrm{ft}$ ( $3 \mathrm{~m}$ ) per second likeiy to be used in OTEC heat exchangers.

Susceptibility to crevice corrosion in flowing sea water may present problems at tube supports in shell-less heat exchangers with water outside the tubes.

It will be necessary to avoid frelting corrostun resulting from vibration of tubes at tube supports in shell and tube heat exchangers. There may also be problems of corrosion fatigue associated with vibration.

Experience showing severe crevice corrosion of aluminum in plate-type heat-rejection heat exchangers in desalination plants would appear to disqualify aluminum for this type of heat exchanger.

The susceptibility of aluminum to accelerated corrosion in galvanic couples with the other metals likely to be used in OTEC systems will require special attention to avoid difficulties from this source. This includes the need to avoid the use of metals, particularly copper alloys, that could contaminate the water with even small traces (parte per billion) of corrosion products upstream of heat exchangers with aluminum tubes. 
Possible effects of ammonia leakage into sea water and vice versa are being investigated. Early test results suggest that the effect of ammonia leakage in triggering deposition of calcium scales from supersaturated sea water is likely to be more important than effects on corrosion. This, plus the cost of even slight ammonia leakage will require extraordinary steps to avoid and detect leakage of ammonia.

A possibly more drastic impediment presented by ammonla is a current U. S. Coast Guard Regulation that prohibits the use of aluminum in contact with ammonia. Results of current tests may provide data that would enable the Coast Guard to waive this prohibition.

Records of service of aluminum in heat exchangers using sea water are not sutficient to qualify aluminum for OTEC heat exchangers. This includes limited experience in desalination plants in which only the heat-rejection exchangers are pertinent.

\section{INTRODUCTION}

At the request of the Central Solar Technology Division of the Department of Energy (DOE) through Argonne National Laboratory (ANL), the writer has reviewed background information on the corrosion of aluminum under conditions to be encountered in Ocean Thermal Energy Conversion (OTEC) heat exchangers. The objective was to determine whether any aluminum alloy could be qualified for this service on the basis of available data.from corrosion tests and service experience.

Since data will continue to become available from current investigations, it may be necessary in the future to modify conclusions in this paper based on the data already in hand. The principal missing factor is possible effects of necessary periodic mechanica1, or possibly chemical, clleaning to remnve organic and inorganic films. Any such effects can be expected to affect estimates of the life of aluminum based on results of tests on specimens not subjected to periodic cleaning. The same missing factor clouds conclusions from service experience, where periodic cleaning has not been involved.

\section{DETAILS PERTINENT TO QUALIFICATION OF ALUMINUM FOR OTEC SYSTEMS COMPONENTS AND, PARTICULARLY, HEAT EXCHANGERS}

Although extensive historical data are available from corrosion tests in sea water, these tests on aluminum, as well as other metals, were not. made under environmental conditions pertinent to OTEC heat exchangers.

The probable protective effect of the extensive accumulations of fouling organisms, such as occurred in static tests in near-surface waters, makes the results of such tests inapplicable to prediction of corrosion behavior in OTEC service where it will be necessary to prevent similar accumulation of fouling or remove it by periodic cleaning. 
Under contract with Battelle-Pacific Northwest Laboratory on behalf of the U. S. Department of Energy, the Alcoa Laboratories of the Aluminum Company of America prepared "Catalog Information on the Performance of Aluminum in Sea Water." 1 The reader is referred to this catalog for the detailed information.

The data on corrosion rates were supplemented in this report by conclusions related to the cataloged data and by references to the sources of these data. The principal conclusions covered in the abstract of this report were the following:

"Pitting and crevice corrosion proved to be the types of attack that predominated. The cataloged data are the results of many static tests conducted under natural conditions of marine fouling, hence, they. must be used carefully in qualifying aluminum for OTEC purposes. These data can serve the OTEC program best as a basis for selecting aluminum alloys that appear promising as candidates for further evaluation. The aluminum alloys 5052 and Alclad (7072) 3003 fall into this category."

It is generally agreed from results of corrosion tests on aluminum that the rate of attack decreases markedly as the duration of exposure increases. This is discussed, for example, in the book by Godard, et al. ${ }^{2}$ and is confirmed by results of more recent tests to be described in this paper.

In several tests, it was found that the maximum pit depth varied with the cube root of time. It has been suggested that the indicated relationship could be accounted for by assuming a mature pit has a hemispherical shape and the extent of corrosion in terms of weight loss or the volume of the pit increases linearly with time. Since the volume varies with the cube of the radius of the pit, the depth of the pit or its radius would be the one-third power of the volume and would increase with the same one-third power of time.

The observations on which this time effect has been based have been on specimens exposed for long periods without disturbance of the metal surface. It does not follow that a similar relationship of progress of pitting with time should be expected under conditions where periodic cleaning might expose fresh surfaces so as to reinitiate corrosion at frequent intervals.

On the other hand, cleaning would reduce the initiation of pitting by providing a more uniform surface free from deposits that might otherwise promote pitting by crevice effects. Uniform corrosion data more directly applicable to periodically cleaned OTEC heat exchangers have been provided from recent tests of the 5052 alloy by Liebert ${ }^{3}$ and by Schrieber, et a1. ${ }^{4}$

Liebert tested the 5052 alloy in sea water flowing at 3 . to $6 \mathrm{ft} / \mathrm{sec}$ at Keahole Point, Hawaii for test periods from 3 hours to 8 months.

Schrieber tested the alloy in sea water flowing at $5 \mathrm{ft} / \mathrm{sec}$ at Freeport, Texas for test periods from 15 to 59 days. 
In both the Schrieber and Liebert tests, the corrosion was uniform with negligible pitting. For the purpose of this paper, Liebert plotted the results of these tests as indicated in Figure 1. The exposure conditions at Freeport were evidently more aggressive than at Keahole Point.

An important characteristic of the results of both programs was that the rates of corrosion decreased as the duration of exposure increased. The progress of corrosion was proportional to the square root of time. Such behavior was consistent with historical data from tests of much longer duration at several locations as described by Godard, et al. ${ }^{2}$ (Table 123, page 130).

The curve in Figure 1, based on data from Schrieber, et a1.5 (Table IX-2) covers tests at an ambient temperature of about $21^{\circ} \mathrm{C}$. The data from Table IX-8 are from tests at about $29^{\circ} \mathrm{C}$. This difference in temperature would account for the higher rates in the latter test. It can be expected that aluminum will be corroded at lower rates in condensers than in evaporators.

It is possible from Figure 1 to estimate the rates of corrosion of the 5052 aluminum alloy and possibly other aluminum alloys such as Alclad 3003 that might be encountered in OTEC heat exchangers subjected to periodic cleaning to maintain heat transfer.

With such cleaning at appropriate intervals, the significant rate of corrosion would be that which would apply to a succession of periods between cleanings. Such rates would be affected by the severity of the effect of cleaning on preservation of protective films formed prior to or during the intervals between cleanings.

It may be possible to devise a cleaning treatment and cleaning cycle that would be able to maintain heat transfer at the desired level without removing a protective film formed prior to cleaning. Under such circumstances, the critical corrosion rate would be that established by the time of the first cleaning and possibly reduced somewhat during periods between successive cleanings.

Studies of effects of fouling on heat transfer have indicated that it. might be possible to maintain heat transfer at the desired level by cleaning at intervals as long as two weeks or one month.

On the basis of the data in Figure 1, if the cleaning treatment did not remove the protective film that had formed in 30 days, the rates of rnrrnsinn that would occur during successive 30-day periods would be from 2 to 3 mils per year based on Schrieber's results and abnitt 1 mil per year based on Liebert's data.

If the cleaning treatment should be sufficiently drastic to restore corrosion to its initial rate, even a 30-day interval between cleanings could result in an intolerable rate of corrosion. More frequent cleaning, e.g., more of ten than once a week, could be catastrophic.

It seems evident that careful attention will have to be paid to the development of effective cleaning treatments that will not remove protective films and to make the intervals between cleanings as long as heat-transfer 


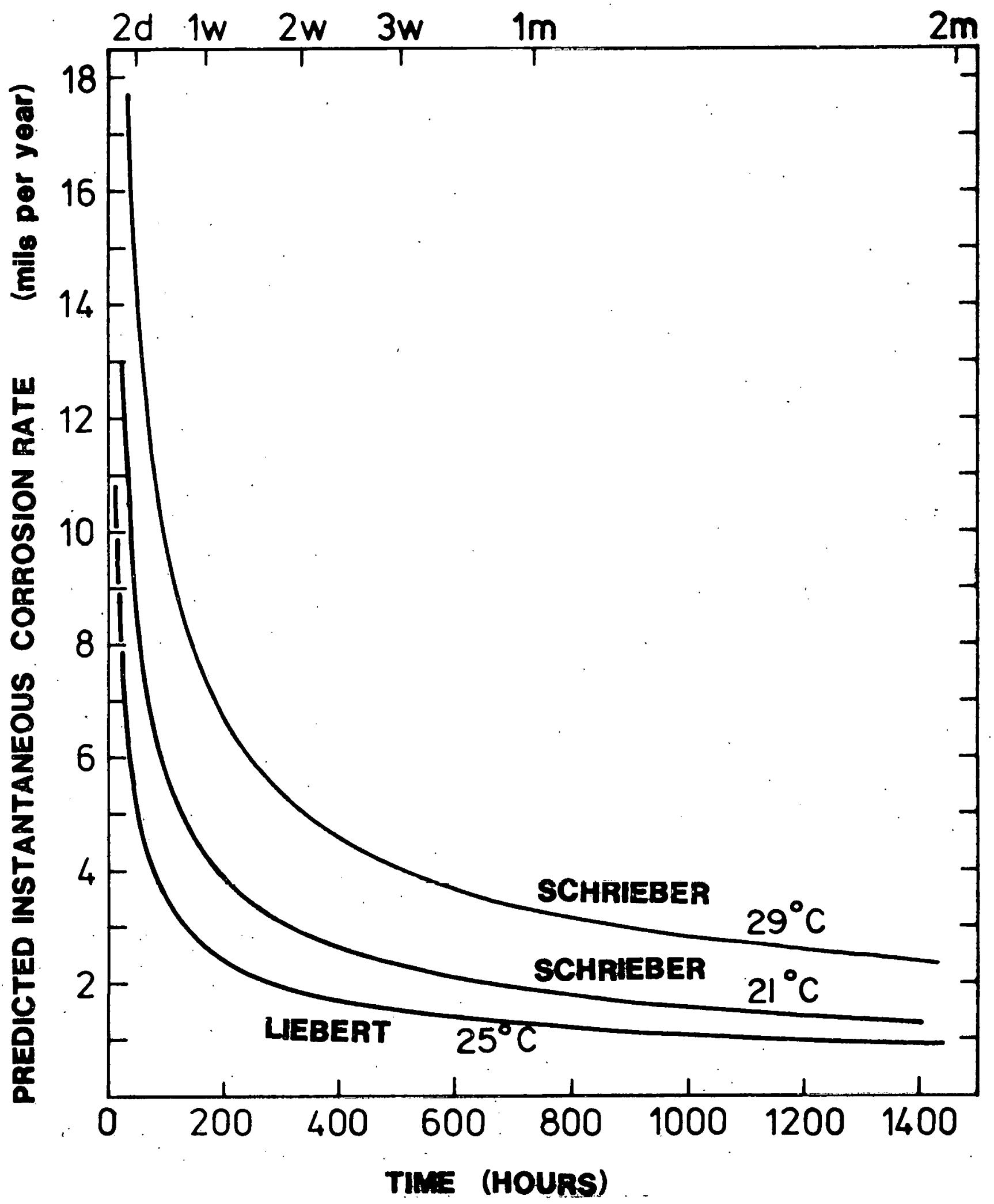

Figure 1. Effect of Time of Exposure on Corrosion of 5052 Aluminum in Sea Water Flowing at 3 to 6 feet per second. 
requirements will permit. Experience with effects of rather drastic mechanical cleaning of aluminum piping has indicated that effects of cleaning methods under consideration for OTEC, such as M.A.N. brushes and Amertap balls, can be tolerated. This expectation needs to be confirmed by an appropriate testing program.

In the meantime, it may be noted that in Liebert's tests a cleaning treatment using 20 passes of a M.A.N. brush at the end of 13,22 , and 29 weeks had a negligible effect on the progress of corrosion.

In Schrieber's tests, specimens were cleaned with 6 passes of brushes to simulate cleaning by M.A.N. brushes after periods of exposure of $1,2,3$, and 7 months and then reexposed for a total of 10 months. The specimens subjected to this periodic cleaning were corroded uniformly at a rate of $1.5 \mathrm{mils}$ per year. This rate was only slightly higher than of uncleaned controls.

Schrieber's tests included effects of various methods of chemical cleaning. The most effective of these was cleaning with $10 \%$ (by volume) sulfuric acid plus $2 \%$ (by weight) chromic acid for 4 hours at ambient temperature. However, this acid treatment increased corrosion to about 2-1/2 times that of uncleaned specimens. It might be expected that acid cleaning could result in restarting corrosion at an initial rate after each cleaning treatment.

Occasional cleaning could reduce the initiation of pitting by providing a more uniform surface free from deposits that might otherwise promote pitting by crevice effects. This would be more important with respect to 50.52 than Alclad.

Unfortunately, Alclad 3003 was not included in Liebert's tests nor in Schrieber's tests. However, in the absence of more specific data, it seems reasonable to assume that the rate of uniform corrosion of the cladding alloy is not greatly different from that of the 5052 alloy.

The important consideration with respect to pitting of Alclad is the life of a sufficient area of cladding to provide cathodic protection against further penetration of the core alloy. The pertinent service records to be described suggest survival of effective cladding for about 1 year per mil (25 $\mu \mathrm{M}$ ) of cladding thickness.

At the present time, the available data on uniform corrosion support the possibility that Alclad aluminum tubes with 10 mils of cladding could survive for about 10 years in an OTEC heat exchanger with cleaning at 30-day intervals to remove fouling. This is based on the assumption that so long as a substantial area of cladding remains there would be no penetration of the 3003 alloy core. It also assumes that the cleaning treatment will not eliminate protection provided by films formed prior to each cleaning.

The 5052 alloy might also have a similar life with respect to uniform corrosion but would be more vulnerable to penetration by pitting. 


\section{PITTING}

For the two alloys of particular interest (5052 and Alclad 3003), there was a very wide scatter of data in the A.lcoa Catalog on depths of pitting in both surface and deep waters.

Those concerned with predicting the life of aluminum tubes in OTEC heat exchangers have evidently been forced to decide which data, from this and other possible sources, should be used as a basis for their estimates of durability based on rates of pitting.

The confusion generated by the need to make such choices is illustrated by the data in Table I. This shows the disparity among the choices by three designers from presumably the same sources of data. These choices are compared with what the present author has abstracted from the Alcoa Catalog.

The data in Table I are presented simply to illustrate the wide range of reported rates of pitting. They are not intended to be used as a basis for estimating the probable life of aluminum in OTEC heat exchangers.

The author has received some unpublished data through the courtesy of T. E. Wright of Alcan Research Laboratory. ${ }^{6}$ This covers results of tests of Alcan IS-1200 for 3 years at Harbor Island, North Carolina. The tests were made on pipes arranged in a telescoping series from 3-inch diameter to $1 / 2$-inch diameter so as to give a range of velocities. The actual velocities varied considerably, since the rate of flow did not remain constant throughout the test period. The actual range was from 0.17 to $1.6 \mathrm{ft} / \mathrm{sec}$ for the 3 -inch pipe and from $4.0 \mathrm{ft} / \mathrm{sec}$ to $38 \mathrm{ft} / \mathrm{sec}$ for the $1 / 2$-inch pipe.

After test, the pipes larger than 2 inches in diameter were found to be covered with "mossy" marine organisms and small barnacles. The effect of these would have been to reduce the velocity to essentially zero at the metal surface beneath the organisms. The range of velocity in the pipes $1-1 / 2$ inches in diameter and smaller in which there had been relatively little persistent fouling by marine organisms was from 0.6 to $5.6 \mathrm{ft} / \mathrm{sec}$ in the 1-1/2-inch-diameter pipe, from 1.6 to $15 \mathrm{ft} / \mathrm{sec}$ in the 1-inch-diameter pipe, from 3.5 to $21 \mathrm{ft} / \mathrm{sec}$ in the 3/4-inch-diameter pipe, and from 6.3 to $38 \mathrm{ft} / \mathrm{sec}$ in the 1/2-inch-diamcter pipe.

The relation between fouling and velocity observed in this test suggests that a sustained velocity in excess of $2.5 \mathrm{ft} / \mathrm{sec}$ can be expected to minimize persistent fouling by macromarine organisms. This is consistent in order of magnitude with results of other observations of the effect of flow velocity on macrofouling, indicating a critical velocity somewhere around $4 \mathrm{ft} / \mathrm{sec}$.

This critical velocity does not apply to fouling by microorganisms such as bacterial slimes. Recent studies of effects of such slimes on heat transfer have shown that bacteria slimes can adhere at velocities up to at least $6 \mathrm{ft} / \mathrm{sec}$.

Corrosion within the complete range of flow velocities was predominantly in the form of multitudes of rather deep pits. The maximum depth occurred at the lowest and highest velocities, as shown in Table II. 
TABLE I. Reported Rates of Penetration of Aluminum Alloys in Sea Water in Mils per Year

\begin{tabular}{|c|c|c|c|c|c|c|c|}
\hline \multirow[b]{3}{*}{ Source* } & \multicolumn{4}{|c|}{ Alloy SUS: } & \multicolumn{2}{|l|}{ : } & \\
\hline & \multicolumn{4}{|c|}{ Maximum } & \multicolumn{3}{|c|}{ Minn证um } \\
\hline & Surface & Water & \multicolumn{2}{|c|}{ Deep Water } & Surface & Water & Deep Water \\
\hline A & & 29 & 65 & & & 0 & 0 \\
\hline B & & 52 & 62 & & & 0 & 5 \\
\hline C & & 29 & 39 & & & 0 & 0 \\
\hline \multirow[t]{2}{*}{$\mathrm{D}$} & & 5 & 35 & & & 0 & 0 \\
\hline & & & Alclad: & 3003 & , & & \\
\hline A & & 13 & 14. & . & . & - & 0 \\
\hline B & & 4 & - & . & & - & 30 \\
\hline$r$. & & 22 & - & & . & 4 & - \\
\hline D & & $1 \cdot 3$ & $x *$ & & & 0.3 & 0 \\
\hline
\end{tabular}

*A Tockheed, 1978 Conceptuạl Deșign Reporr.

B Westinghouse, 1978 Conceptual Design Report.

C TRW, 1978 Conceptual Design Keport.

D Alcoa, Abstracted from Aloca Catalog by present author.

* Depth of pitting was $20 \mathrm{mils}$ in 123 days at which time a large area of cladding was gone. 
TABLE II. Maximum Depths of Pitting of Aluminum 1200 in Sea Water Flowing Through Pipes at Ambient Temperature for Three Years at Harbor Island, North Carolina

\begin{tabular}{lccc}
\hline $\begin{array}{l}\text { Nominal Pipe } \\
\text { Size (inches) }\end{array}$ & $\begin{array}{c}\text { Range of Flow } \\
\text { Velocity during Test } \\
\text { (ft/sec) }\end{array}$ & $\begin{array}{c}\text { Pit Depths } \\
\text { (mils) }\end{array}$ & Fouling \\
\hline 3 & 0.17 to 1.6 & 58 & Considerable \\
$2-1 / 2$ & 0.26 to 2.4 & 54 & $\begin{array}{c}\text { Considerable } \\
\text { Considerable }\end{array}$ \\
$1-1 / 2$ & 0.36 to 3.4 & 35 & None \\
1 & 0.6 to 5.6 & 34 & None \\
$3 / 4$ & 1.6 to 15 & 34 & None \\
$1 / 2$ & 2.3 to 21 & 46 & None \\
\hline
\end{tabular}

*Perforated. 
It would appear from these data that there was no controlling effect of the marine growths on the extent of pitting and that a velocity intermediate between the lowest and highest, e.g., around $5 \mathrm{ft} / \mathrm{sec}$, was less aggressive than higher or lower velocities.

The results of this test program have probably limited application to the qualification of aluminum alloys for OTEC heat exchangers because of uncertainties related to the wide ranges of flow rates in the different size pipes and interrelated effects of fouling organisms that would not exist in OTEC service.

Additionai data have been provided by another test of aluminum in the form of pipes at Harbor Island. This was undertaken in an effort to qualify aluminum for use in seawater piping systems by the U. S. Navy. ${ }^{7}$

The epecimene wore in the form of l-inch pipe with a wall thickness of 0.133 inch. The alloys tested were 3003, Alclad 3003, and 5052.

'I'wo 32-inch lengths of each alloy were assembled in lines contalining a $90^{\circ}$ short radius Saran elbow to induce a turbulence effect. The flow velocity was $10 \mathrm{ft} / \mathrm{sec}$. The assemblies were downstream of, but insulated from, a system containing copper-nickel alloys. The tests were run from 30 to 42 months for the 3003 pipes and 12 and 24 months for the Alclad 3003 and 5052 alloys. Apparently there was no fouling of the pipes in this test.

Corrosion was in the form of pitting not initiated by intergranular attack. There was erosion of the inlet edges. This did not occur downstream of the elbows. The extent of pitting is shown in Table III.

The investigators concluded that either 3003 or Alclad 3003 piping with a 0.133-inch wall might have a life expectancy of 10 years. The 5052 alloy was conșidered to be inferiorior.

Recent designers of O'IEC heat exchangers have reached varying conclusions as to the expected life of aluminum tubes in OTEC service. One designer calculated that aluminum tubes would have to be replaced at least once in 30 years. Another designer, using a more conservative estimated life of 10 years, figured on two replacements in the same period. The cost of such replacements will have to be factored into comparisons of the total cost of aluminum as compared with materials that are expected to survive for 30 years without replacement. The precision of such economic comparisons will benefit from additional research being undertaken to provide an improved basis for estimating the probable life of aluminum in OTEC heat exchangers.

\section{CURRENT CORROSION RESEARCH}

The current research program on corrosion of aluminum includes an effort to account for the severe pitting of some aluminum alloys at depths from which condenser cooling water may be taken. 8

Dexter ${ }^{9}$ has given special attention to individual and possibly synergistic effects of critical levels of $\mathrm{pH}$ and oxygen concentration. The results of this research will aid in the characterization of the water at proposed OTEC plant locations with respect to the possibility of encountering water that might have exceptional capacity to promote pitting of aluminum. 
TABLE III. Pitting of Aluminum Pipes in Sea Water Flowing at $10 \mathrm{ft} / \mathrm{sec}$ at Ambient Temperature at Harbor Island, North Carolina

\begin{tabular}{rcc}
\hline Alloy & $\begin{array}{c}\text { Maximum Depth } \\
\text { of Pitting } \\
\text { (mils) }\end{array}$ & $\begin{array}{c}\text { Duration of Exposure } \\
\text { (months) }\end{array}$ \\
\hline 3003 & 40 & 42 \\
Alclad 3003 & $19 *$ & 24 \\
5052 & 41 & 24 \\
\hline
\end{tabular}

*Pitting was confined to the cladding and did not penetrate into the 3003 core. 
Programs carried out at Keahole Point, Hawaii and St. Croix, Virgin Islands, were designed to study the effects of fouling on heat transfer at flow velocities that might be encountered in OTEC exchangers. Unfortunately, the 6061 aluminum alloy used in these tests was chosen by those concerned primarily with heat transfer because of its ease of machining for use in the heat-transfer test device. The corrosion resistance of this alloy is well below the level of the 5052 alloy or Alclad 3003, the preferred candidates for OTEC service.

\section{RESULTS OF TESTS IN HAWAII}

Aluminum 6061 alloy tubes that had been used in CMU devices 10 for heattransfer studies off a vessel moored in 250 feet of water off Keahole Point, Hawaii at $24^{\circ} \mathrm{C}$ were examined for corrosion effects at Battelle-Pacific Northwest Laboratory. 11 One set of specimens was from heat-transfer devices operailug at $3 \mathrm{ft} / \mathrm{sec}$ for 10.1 weeks and at $6 \mathrm{ft} / \mathrm{sec}$ for 5.4 weeks. Another set was the pipes upstream of the heat-trallsfer devices.

All specimens suffered attack at grain boundaries. There was no difference between the attack on the heat-transfer pipes and the upstream pipes. The maximum depth of 1ntergranular attack was 7.9 mils in the 10-week tests at $3 \mathrm{ft} / \mathrm{sec}$ and $2 \mathrm{mils}$ in the 5 -week tests at $6 \mathrm{ft} / \mathrm{sec}$.

Similar intergranular attack would not be expected for the more corrosionresistant 5052 and Alclad 3003 alloys.

More pertinent tests on the 5052 alloy at Keahole Point were reported by Liebert ${ }^{3}$ as discussed previously.

Other tests at Keahole Point simulated operations of a shell-less heat. exchanger using Alclad 3004 tubes with the water outside the tubes. The observations were concerned principally with measuremeuts of reduction of heat transfer by fouling organisms and efforts to remuve fouling by pcriodic scrubbing.

A "dummy" Alclad 3004 tube, made from strip by welding, included in the test array was examined for corrosion by Liebert. After exposure for 12 weeks, pitting had extended rather generally to the depth of the cladding, which was about 0.001 inch thlck. The same depth of arcack ovel mors axtended areas was found by Summerson ${ }^{12}$ on similar tubes that had been in test for four months.

Examination of the weld metal showed that it was free from p1ts, having been protected by the adjacent cladding. One section of the weld exhibited what was described as "atypical" interdendritic corrosion to a depth of about 5 mils.

The results of this test are clouded by the fact that the sea water in contact with the aluminum tubes came through a cast iron pump which intruduced iron corrosion products such as were found by Liebert in his examination of the pits that had formed. 


\section{TESTS AT ST. CROIX}

As was the case in the Hawaii tests, the corrosion studies at St. Croix were in conjunction with heat-transfer studies. The test assemblies were mounted on a barge moored offshore of St. Croix. Water was taken from a depth of $60 \mathrm{ft}$.

Here again, the alloy was 6061-T6, in the form of pipe, either CMU units or independent of these units but subjected to the same rates of flow, 3 and $6 \mathrm{ft} / \mathrm{sec}$. Additional specimens were exposed to quiescent water at the same location. Two specimens of the 5052 alloy were also tested for 2 weeks.

The corrosion experiments were under the supervision of Munier and Craig of the University of Miami. 13

The sea-water conditions were as follows:

$\begin{array}{ll}\text { Temperature } & 28^{\circ} \mathrm{C} \\ \text { Salinity } & 35-36 \\ \text { Dissolved } 0_{2} & 4.3 \text { to } 4.8 \mathrm{ppm} \\ \mathrm{pH} & 8.2 .\end{array}$

Specimens for examination for corrosion were removed at time intervals from. 2 to 72 days.

The test system included devices for electrochemical measurements of corrosion potentials and for estimating rates of corrosion assumed to be uniform for such calculations.

None of the pipe specimens outside the CMU devices or the specimens exposed in quiescent water suffered any measurable pitting.

The specimens from the CMU devices suffered pitting, which was. most severe in the test at $3 \mathrm{ft} / \mathrm{sec}$.

The pits in the CMU specimens at $6 \mathrm{ft} / \mathrm{sec}$ flow velocity were very shallow, $1 \mathrm{~mm}$ in diameter, and distributed randomly. The pitting of CMU specimens at $3 \mathrm{ft} / \mathrm{sec}$ flow velocity was relatively severe in bands in the direction of extrusion and less severe elsewhere in random distribution. The depth was shallow but the pits were larger in diameter, $2-5 \mathrm{~mm}$, than in the $6 \mathrm{ft} / \mathrm{sec}$ specimens. The pits had become filmed over and apparently were no longer active.

It was suggested that the pitting of the specimens in the CMU devices may have been due to leakage of current from some unidentified source in the electrical system on these devices. No effort was made to trace the path of any such "stray current" leakage.

No similar difference in extent of corrosion was observed in similar test arrays in Hawaii. 
The CMU specimens at St. Croix were from a different source and were given different surface preparations. This could account for the difference in corrosion, such as the concentration of pits in the direction of extrusion on CMU specimens.

There was no pitting of the quiescent specimens of the 6061 alloy.

There was no pitting of the 5052 alloy pipe specimens in the 2-week test.

Potential measurements were said to be consistent with the absence of pitting on the specimens outside the CMU devices. There were no potential measurements for the CMU specimens that had pitted.

The estimated rate of uniform corrosion for the 6061 alloy, based on potential measurements, was 1.5 mils per year.

The Invesclgaturs cuncluded that the results of these tests would qualify aluminum alloys 6061-T6 and 5052 as candidates for OTEC heat-exchanger service.

\section{TESTS IN THE GULF OF - MEXICO}

Additional tests are under way in the Gulf of Mexico.14 One project involves a set-up on a large buoy operated by the National Data Buoy Office. The other is at a station on shore at Panama City, Florida, carried out by the Naval Research and Development Center. 15

These projects involve measurements of corrosion as well as effects of fouling on heat transfer and various means of preventing fouling or removing it by cleaning.

There have been no detailed reports on corrosion effects at either of these fult nt Mexico test locations.

Additional corrosion tests of candidate aluminum alloys under OTEC service conditions will be made at other locations in the future.

\section{VTTT. . CREVICE CORROSION}

Aluminum is subject to crevice corrosion under condtlunb lhat way exist in OTEC heat exchangers. This is more likely to be encountered in designs such as shell-less heat exchangers with water outside the tubes where crevices may be formed by tube supports, and in plate-type heat exchangers at points of contact between overlapping plates and under gaskets.

The danger of serious corrosion in plate-type heat exchangers is illustrated by experience with such an exchanger operated in a freezing process desalination unit using freon at the office of Water Technology demonstration plant at Wrightsville. Beach, North Carolina. This heat exchanger was used to precool incoming sea water with product water or brine. 'lypical plates made of the 3003 alloy 0.025 inch thick were removed for examination after service for about 3 years and actual contact with sea water for about half that period. 
Crevice corrosion to a depth of about $12 \mathrm{mils}$ had occurred at several points of contact between overlapping plates. In addition, there was one perforation of a 0.025 -inch-thick plate, again at a contact point.

Similar crevice corrosion was said to be responsible for failure of aluminum (alloy not identified) in plate-type heat-rejection condensers in a desalination plant in Israel, which was described by Friedman ${ }^{16}$ as follows:

"The (aluminum) plates were attacked mainly by crevice corrosion, as aluminum plates could not stand up to the severe conditions, titanium plates are now installed.":

Crevice corrosion of Alclad 3003 was observed in the deep submergence tests reported by Reinhart. ${ }^{8}$ The most severe crevice attack to a depth of 15 mils with most of the cladding gone occurred in exposure for 123 days at a depth of 5460 feet. This was accompanied by pitting to a maximum depth of 18 mils.

Crevice corrosion of Alclad did not occur in surface water over a period of 588 days, but there was pitting to a depth of $17 \mathrm{mils}$ in this test.

The 5052 alloy is also subject to crevice corrosion. In Reinhart's tests, specimens were attacked to a depth of $65 \mathrm{mils}$ in 123 days at a depth of 5640 feet. There was no pitting outside the crevice.

In surface water, the maximum depth of crevice corrosion was 5 mils in 366 days with pitting to the same depth outside the crevice.

As was the case with the Alclad 3003 alloy, the results of these tests suggest that crevice corrosion may be more severe in condensers using deep water than in evaporators using surface water. The reverse may be true with respect to pitting.

In any event, Alclad would be expected to have a better chance than unclad alloys in resisting corrosion in crevices.

Crevice-corrosion tests of the aluminum 6061 alloy by Peterson and Leniux ${ }^{17}$ at key West, Florida, showed that a modest increase in velocity of movement of sea water greatly increased the severity of crevice corrosion.

Specimens of the 6061 alloy suffered crevice corrosion to a depth of $8 \mathrm{mils}$ in 2 years in quiet surface water. Similar specimens exposed to water flowing in a flume at a velocity of $0.75 \mathrm{ft} / \mathrm{sec}$ were perforated $(0.0625 \mathrm{in}$. during the 2-year test period).

Comments on crevice corrosion in the Alcoa Catalog ${ }^{1}$ included the following:

"The existing data do not show to what extent crevice corrosion would be encountered on aluminum in OTEC power plant heat exchangers. OTEC heat exchangers should be designed to avoid crevices." It was suggested that crevices 
might be avoided "through the use of appropriate gaskets and sealants and increasing the tightness of joints." In this context it will be necessary to ensure that the gasket or sealant be firmly and continuously bonded to the metal so as not to create another crevice.

\section{EFFECTS OF FLOW VELOCITY}

The oxide films on which aluminum depends for resistance to corrosion could be eroded by shear forces resulting from flow over the surface above some critical velocity. A limited amount of data, 18 including those from the. Navy Engineering Experiment Station, ${ }^{7}$ indicate that such a critical velocity is likely to be over $10 \mathrm{ft} / \mathrm{sec}$ and, therefore, above the $6 \mathrm{ft} / \mathrm{sec}$ proposed for OTEC shell and tube heat exchangers and the lower velocity in the shell-less heat exchangers proposed by the Johns Hopkins Applied Physics Laborntory.

The manner by which the velocity of flow is achleved in a LesL can liave a considerable influence on its. damaging effect. A uniform high velocity over the entire test surface, such as existed in the test referred tol 8 is likely to be less damaging than a localized high velocity such as achieved by a submerged jet.

The local removal of a protective film adjacent to filmed surfaces can set up local corrosion cells causing accelerated attack where the film has been removed.

Such localized velocity effects could very well restrain the use of submerged jets for cleaning the outer surfaces of aluminum tubes in she11less heat exchangers with the water outside the tubes.

The reality of this possible restraint on the use of jets for cleaning should be cstablished by an appropriate test program.

A similar limitation may be imposed on the use of high-frequency vibration for clcaning. This could result in cavitation erosion such as is created by tests using high-frequency vibration 19 to evaluate resistance to cavitation erosion. Aluminum has been found to have a very low resistance to cavitation erosion by tests of this kind. 20 .

In the absence of abrasive material in suspension, it is conceivable that a modestly high velocity, e.g., the $6 \mathrm{ft} / \mathrm{sec}$ proposed for O'lEC heat exchangers, could be favorable to a good performance of aluminum as well as other metals. The beneficial effect would be the prevention, or removal, of various deposits that might otherwise promote localized attack in crevices under such depusils.

The additional corrosion tests being carried out at several locations will permit observations of effects of flow velocity that were not involved in the tests which have provided most of the historical data on corrosion of aluminum as discussed elsewhere in this report.

An increase in flow velocity would be expected to.aggravate crevice corrosion, as observed in the tests by Peterson and Lennox. 17 


\section{GALVANIC EFFECTS}

The vulnerability of aluminum to acceleration of corrosion by galvanic action in contact with most other metals needed for OTEC system components and by effects of heavy metals (copper) from corrosion upstream of aluminum components will limit choices of materials for such components. This could increase costs of such components and limit means of avoiding fouling in piping, screens, and water boxes by use of antifouling coatings containing copper or of copper alloys naturally resistant to fouling by barnacles, etc. If antifouling coatings are to be used, they should be based on tributyl tin rather than copper.

Steel piping and water boxes could be coated to avoid galvanic and iron corrosion product, including detached scale, and effects on associated aluminum. Epoxy formulations have been proposed as being appropriate coatings. These should be supplemented by cathodic protection to take care of possible bare spots. There have been reports of adverse effects of detached particles of coatings.

Cathodic protection at much higher current densities could conceivably be effective with bare pipes and water boxes.

There have been reports of difficulties with relatively thick elastomeric or similar coatings as a result of loss of adhesion with subsequent clogging of downstream components by detached coatings.

Coating of steel with aluminum has been proposed as a more cost-effective alternative. Consideration would be given, also, to the use of solid aluminum for water boxes and tube plates.

\section{EFFECT OF CHLORINATION}

It seems likely that chlorination will be used as a supplement to mechanical cleaning to maintain the desired level of heat transfer. Chlorination will also be necessary to control macrofouling, especially in conjunction with the use of aluminum in heat exchangers, which would restrict the use of copper alloys for components upstream of the aluminum.

The concentration of chlorine likely to be used, e.g., less than $0.2 \mathrm{ppm}$, is not expected to aggravate corrosion of aluminum.

\section{EFFECTS OF AMMONIA}

The possibility of serious corrosion of aluminum as a result of leakage of ammonia into sea water was suggested by results of tests with very dilute concentrations of ammonia in pure water. ${ }^{1}$ In these tests, mixtures with sea water were found to be less aggressive.

Such possible effects have been investigated in a program undertaken by Schrieber and associates ${ }^{4}$ at Freeport, Texas. These tests covered a range of ammonia additions from 8 to 800 parts per million at 5 and $30^{\circ} \mathrm{C}$ and flow velocities of 2.5 and $5.6 \mathrm{ft} / \mathrm{sec}$. 
The $8 \mathrm{ppm}$ concentration of ammonia was most aggressive in increasing the extent of pitting at both 5 and $30^{\circ} \mathrm{C}$ as compared with sea water containing no ammonia. In the case of the 3003 alloy, pitting at $30^{\circ} \mathrm{C}$ increased from practically zero to $14 \mathrm{mils}$ in 64 days at the $2.5 \mathrm{ft} / \mathrm{sec}$ velocity. With the 5052 alloy, pitting increased to $21 \mathrm{mils}$ in 64 days under the same test conditions.

The effect of $8 \mathrm{ppm}$ of ammonia was less at the $5.6 \mathrm{ft} / \mathrm{sec}$ velocity. Ammonia concentrations greater than $8 \mathrm{ppm}$ were less damaging under all the testing conditions.

The presence of ammonia did not increase rates of uniform corrosion.

The observed effects of ammonia on corrosion of aluminum are much less serious than the much more important effect of ammonia in precipitating calcium carbonate that would serve as nuclei for the further precipitation of scale from water likely to be supersaturated in calcium carbonate. Such deposition of scale was observed in this test program. Since the scale resulting from such precipitation would be intolerable in OTEC heat exchangers, there will be a need, for this reason, to avoid even slight leakage of ammonia, irrespective of possible effects on corrosion of aluminum.

This need to take extraordinary steps to avoid, detect, and correct leakage of ammonia extends as well to heat exchangers using any other metal for tubing.

The effect of ammonia leakage in forming scales would be most critical in plate-type heat exchangers in which nuclei originating from a leak in one plate could result in precipitation of scale on all downstream plates.

It is possible, also, that scale precipitation nuclei could be transported by M.A.N. brushes or Amertap balls from a local source in a tube. to the main body of water in a water box.

The tests by Schrieber, et al. ${ }^{4}$ extended to possible effects of leakage of sea water into ammonia to the extent of $0.14 \%$. Their results indicated that such leakage would not present a problem of accelerated corrosion of aluminum nor deposition of scale.

Economic considerations will also require avoidance of even slight ammonia leakage, for example, leakage sufficient to add $1 \mathrm{ppm}$ to the sea water in a 250-megawatt OTEC plant would result in an intolerable loss of 20 tons of ammonia per day.

Currently there is a possible obstacle to the use of aluminum in a system involving ammonia. U. S. Coast Guard Regulation CG-257 prohibits the use of aluminum for components that come in contact with ammonia. The basis for this exclusion is obscure. It is possible that the Coast Guard could be persuaded to waive this prohibition on the basis of existing data and experience plus the results of the additional corrosion tests undertaken by Schrieber., et a1. ${ }^{4}$ 
A pending IMCO (Inter-Governmental Maritime Consultative Organization) Standard (Section 154, 1700, Table 4) does not prohibit the use of aluminum in contact with ammonia. This conflict with the Coast Guard Regulation would presumably be taken into account by the Coast Guard in reaching a final decision on waiving their prohibition of aluminum in OTEC ammonia systems.

\section{EFFÉCTS OF VIBRATION}

\section{A. Corrosion Fatigue}

The relatively low corrosion fatigue strength of aluminum alloys, e.g., from 3000 to 8000 psi as shown by conventional rotating beam tests in seawater, ${ }^{21}$ has led to attention to calculation of the extent of danger from this source. These studies have indicated that corrosion fatigue of tubes in heat exchangers need not present a problem with proper spacing of tube supports.

\section{B. Fretting}

There have been instances of severe deterioration of aluminum tubes as a result of vibration in tube support plates. The Alcoa Catalog drew attention to this with a photograph of a particularly severe example along with erosion by high-velocity steam in the same installation. They concluded that the need to minimize vibration was related more to avoiding damage by fretting than by corrosion fatigue.

\section{SERVICE RECORDS}

There are not many records of service related to OTEC heat exchangers. The situation was summarized in the Alcoa Catalog of datal by the following quotation:

"Available service histories also proved inadequate for qualifying aluminum alloys for the OTEC application, but they do support the sclection of Alclad (7072) 3003 as a tublng alloy worthy of further consideration. Performance data covering areas of investigation peculiar to OTEC power plants is needed to permit a firm decision for or against aluminum alloy tubes."

Exclusion of reference to the 5052 alloy in this quotation from the Alcoa report may have been inadvertent, since elsewhere in the report the 5052 alloy was identified as a "promising candidate for further evaluation."

More recently, representatives of the aluminum industry have identified Alclad 3003 or 3004 as being the most likely to qualify as economical materials for tubes in OTEC heat exchangers.

There is a need, alsu, fur an evaluation of the relative cost of rollformed and welded Alclad tubes as compared with extruded material. The rollformed tubing could be considerably cheaper. It is available in enhanced surface configurations.

Reference was made previously to failure of aluminum in plate-type heatrejection condensers in Israel 16 decalination plants. 
The most pertinent service records are the following:

Alclad 3003 tubes 3/4-inch OD with a 0.064 inch wall were used in an oil cooler on the S. S. Alcoa Clipper. ${ }^{1}$ After 10 years, 24 percent of the 0.01 inch 7072 cladding remained with no penetration into the 3003 core.

A generally similar life was shown by Alclad used for salt-water piping in the Royal Canadian Navy as described by Rogers and Chinn. ${ }^{22}$ Services involved circulatory lines to the main engines, sanitary lines, and auxiliary equipment with flow velocities from 5 to $10 \mathrm{ft} / \mathrm{sec}$. Experience with Alclad 3003 showed gradual loss of large areas of cladding 0.013 inch thick after service for 8 years.

Despite loss of large areas of cladding, there was no penetration into the 3003 alloy sore.

The authors estimated that a 10-year Lite would be expected from 4-1nch pipe with $0.013-i n c h$ cladding in this service.

The installations in the Royal Canadian Navy also included piping of the 5052 alloy in the same service as the Alclad 3003. The performance of the 5052 alloy was quite unsatisfactory. Failures by perforation were experienced in less than 2 years.

\section{EXPERIENCE IN OTHER HEAT EXCHANGERS}

It is difficult to relate experience with aluminum in heat exchangers in other services such as in power plants to qualification of aluminum for OTEC applications. Water-side damage that occurred could have been from effects of suspended sediments and corrosive constituents that would not be present in clean sea water. The situation is illustrated by attempts several years ago to use aluminum tubes in condensers in nine power plants. ${ }^{23}$ The pertormance of the aluminum was generally unsatisfactory because of steam erosion, water erosion, and pitting.

Attention to.problems disclosed by early experience resulted in improved performance in later power plant installations mostly using fresh water for cooling. These were discussed in a paper by Horst and Marchese. 24 .

\section{XVT. STIMMARY OF SFRVTSF, RF,CORDS}

The experienre with the nit conler on the Alcoa Clipper and with the piping in the Royal Canadian Navy, although not directly related to OTEC heat exchangers, subjected to periodic mechanical cleaning, supports the possibility that Alclad 3003 tubes could survive for 10 years in OTEC heat exchangers. This estimate is supported by test data in the present paper on the progress of uniform corrosion with time.

The data with respect to the 5052 alloy are less encouraging. This is illustrated, for example, by the performance of the 5052 alloy in comparison with Alclad 3003 in the piping installations in the Royal Canadian Navy. 
The ability of cladding to arrest pitting penetration of the core should be particularly attractive for thin-wall heat-exchanger tubing where resistance to local penetration is especially important.

Nevertheless, the 5052 alloy should remain a candidate for further evaluation in test programs. But, if limitations of funds or facilities for further evaluation should require a choice between the 5052 alloy and Alclad, the preference should be given to Alclad.

There is a possibility that the life of cladding could be extended by the development of a less active cladding alloy, e.g., one with a lower zinc content. There appears to be less scope for finding an effective cladding alloy for use over the 5052 composition, which has a higher corrosion potential than the 3003 alloy. 


\section{REFERENCES}

1. R. H. Wagner and R. A. Bonewitz, "Catalog Information on the Performance of Aluminum in Sea Water," Pacific Northwest Laboratory, PNL-2606, Alcoa Report No. NXS-3, April 5, 1978.

2. H. P. Godard, W. B. Jepson, M. R. Bothwell, and R. L. Kane, "The Corrosion of Light Metals," Wiley, New York, 1967.

3. B..E. Liebert, "Corrosion of Aluminum and Titanium at Keahole Point Over an Eight Month Period," Proc. of the Ocean Thermal Energy Conversion (OTEC) Biofouling, Corrosion, and Materials Workshop, Rosslyn, VA, Argonne National. Laboratory, ANL/OTEC-BCM-002, in press.

4. C. F. Schrieber, W. D. Grimes, and W. F. McIlhenny, "Interleakage of Ammonia and Seawater in U'l'EL Heat Exxchangers - Effects on Corrosion and Scale Formation," Proc. of the Ocean l'hermal Energy Conversion (OTEC) Biofouling, Corrosion, and Materials Workshop, Rosslyn, VA, Argonne National Laboratory, $\Lambda$ NL/OTEC-BCM-002, in press.

5. C. F. Schrieber, W. D. Grimes, and W. F. McIlhenny, "A Study of the Corrosive Effect on Aluminum and CP Titanium of Mixtures of Ammonia and Seawater That May Be Encountered in OTEC Heat Exchangers," Dow Chemical U. S. A., Texas Division, Freeport, TX; Argonne National Laboratory, ANL/OTEC-BCM-004, in press.

6. T. E. Wright, Alcan Research Laboratory, Kingston, Ontario, Canada, private communication.

7. U. S. Navy Engineering Experiment S̈tation Report 0-40037A(5), February 28,1955 .

8. F. M. Rcinhart, "Corrocion of Metale and Alloys in the Leep Ucean," Rcport No. $T \cdot R$ 834, Civil Enginccring Laboratory, Naval Construction Battalion Center, Port Hueneme, CA, February 1976, 265 pages.

9. S. C. Dexter, University of-Delaware, Lewes, DE, private communication.

10. J. G. Fetkovich, G. N. Grannemann, L. M. Mahalingam, D. L. Mcicr, and F. C. Munchmeyer, "Studies of Biofouling in Ocean Thermal Energy Conversion Plants," Proc. Fourth Ann. OTEC Conl., G.E. Toup, Ed., New Orleans, March 1977, pp. VII-15-VII-23.

11. 3. J. Thompson and G. E. Zima, "Letter Report on Corrosion of OTEC Heat Exchanger Tubing, Keahole Point, Hawaii," Battelle-Pacific Northwest Laboratory, May 1978.

12. T. J. Summerson, Kaiser Aluminum and Chemical Corp., private communication. 
13. Robert S. C. Munier and H. Lee Craig, "Ocean Thermal Energy Conversion (OTEC) Biofouling and Corrosion Experiment (1977), St. Croix, U. S. Virgin Islands, Part II, Corrosion Studies," Tracor Marine, Inc.; Pacific Northwest Laboratory, PNL-2739, Part II, February 1978.

14. Results of tests in the Gulf of Mexico to be reported by the National Data Buoy office, 1979.

15. Results of tests at Panama City, Florida, to be reported by the Naval Systems Research and Development Command, 1979.

16. M. Friedman, "Operational Experience of Vapour Compression Plants," Proc. of the Eleventh National Symposium on Desalination, Oslo, March 1975.

17. M. H. Peterson and T. J. Lennox, Jr., "The Effects of Exposure Conditions on the Corrosion of 6061-T6 Aluminum in Sea Water," Materials Performance, April 1977, pp. 16-19.

18. J. Symonds, "Effect of Velocity on the Seawater Corrosion Resistance of Two Aluminum Alloys," Proc. of the Fifth Ocean Thermal Energy Conversion Conf., Miami. Beach, FL, February 1978, CONF-780236, Vo1. 4, pp. VIII-222-VIII-230.

19. S. L. Kerr, Trans. ASME, 59, 373 (1937).

20. M. S. Plesset, Corrosion, 18, 5 (1962).

21. E. J. Czyryea, "Corrosion Fatigue Tests of Aluminum Alloys for Surface Effect Ship Hulls," NSRDL, Corderock, 'MD, Report No. 28-363, October 1972.

22. T. H. Rogers and W. K. Chinn, "Uses and Abuses of Aluminum in Woodenhulled, Aluminum-frame Minesweepers," Corrosion, 15, 403t-408t (August 1959).

23. "Aluminum Condenser Tubes, A Status Report," Power, March 1963.

24. R. L. Horst and R. T. Marchese, ASME, Paper No. 62 WA-330, Nuvember 1962. 
Distribution for ANL/OTEC-BCM-003

Internal:

P. H. Benson

J. B. Darby, Jr.

J. E. Draley (15)

B.R.T. Frost

A. B. Krisciunas

G. F. Popper

J. J. Roberts

N. F. Sather

A. Thomas

ANL Contract Copy

ANL Libraries (5)

TIS Files (6)

External:

DOE-TIC, for distribution per UC-64 (412)

Manager, Chicago Operations and Regional Office, DOE

Chief, Office of Patent Counsel, DOE-CORO

President, Argonne Universities Association

I. Hithert. Anderson. Sea Solar Power, Inc.

M. Kent Anderson, Trane Air Condition1,ng

Takaaki Anzai, Florida Institute of Technology

W. H. Avery, Applied Physics Laboratory, Johns Hopkins University

E. Barsness, Westinghouse Electric Corporation

James 0. Bates, Energy Technology Engineering Center

Kenneth J. Bell, Oklahoma State University

Robert A. Bonewitz, Aluminum Company of America

R. Cohen, US-DOE, Div. of Central Solar Technology

William A. Corpe, Columbia University

R. S. Dalrymple, Reynolds Metals Company

G. J. Danek, Annapolis, Maryland

James Denton, TRW Systems and Energy

John DePalma, U. S. Naval Oceanographic Office

Stephen Dexter, University of Delaware

John G. Fetkovich, Carnegie-Me11on University

Harry Foust, Trane Air Conditioning

Ma.T.com D. Fraser, Intertechnology Corporation

John Gertz, Westinghouse Electric Corporation

Sigmund Gronich, US-DOE, Div. of Central Solar Technolugy

P. H. Hadley, Jr., Gibbs \& Cox, Inc.

L. W. Hallanger, Research Corporation, University of Hawaii

William Hartt, Florida Atlantic University

William E. Heronemus, University of Massachusetts

F. K. Hill, Applied Physics Laboratory, Johns Hopkins University

Jules Hirshman, Tracor Marine

J. F. Jenkins, Civil Engineering Laboratory

E. H. Kinelski, US-DOE, Div. of Central Sular Technology

Robert E. Laccy, Southeru Researrh Ingtitute

F. L. LaQue, Verona, New Jersey (2)

Abrahim Lavi, Carnegie-Mellon University

T. S. Lee, International Nickel Company

Murray Leitner, Lockheed Missiles and Space Co., Inc.

Lloyd Lewis, US-DUE, Div. of Central Solar Technology

Brenda Little, NORDA

D. Lott, Naval Coastal Systems Center

Richard N. Lyon, Oak Ridge National Laboratory

Frank Mathews, Colorado School of Mines 
William F. McIlhenny, Dow Chemical

John W. Michel, Oak Ridge National Laboratory

Ralph Mitchel1, Harvard University

Robert L. Molinari, NOAA/AMOL

John Morse, University of Miami

John Nicol, Arthur D. Little, Inc.

Merle Olmsted, General Electric Company

T. B. O'Neill, Civil Engineering Laboratory

David Price, U. S. National Oceanic and Atmospheric Administration

W. W. Pritsky, Aluminum Association

J. F. Rynewicz, Lockheed Missiles and Space Co., Inc.

Donald Sasscer, University of Puerto Rico

H. H. Sephton, University of California at Berkeley

William Sheppard, NOAA Data Buoy office

Wilbur Sherwood, US-DOE, Div. of Central Solar Technology

J. E. Snyder, TRW Systems and Energy

Frank Spiehler, NOAA Data Buoy Office

T. J. Summerson, Kaiser Aluminum and Chemical Corp.

R. B. Tee1, Chatham, New Jersey

D. L. Thomas, Radiation Management Corporation

Fred Vukovich, Research Triangle Institute

J. Paul Walsh, Value Engineering Company

E. T. Wanderer, Aluminum Company of America

Ralph Williams, PRC Energy Analysis Co.

David C. White, Florida State University

Hank White, Natural Energy Laboratory of Hawaii 